\section{The Effect of Scaffolded Think-Group-Share Learning on Indonesian Elementary Schooler Satisfaction and Learning Achievement in English Classes}

Octavia Mantik ${ }^{a}$, Hee Jun Choi ${ }^{b},{ }^{*}$

$\begin{array}{ll}\text { Received: } & 22 \text { August } 2017 \\ \text { Revised: } & 20 \text { October } 2017 \\ \text { Accepted: } & 25 \text { October } 2017 \\ \text { ISSN: 1307-9298 } & \text { Copyright } \odot \text { IEJEE } \\ \text { www.iejee.com }\end{array}$

DOI: $10.26822 /$ iejee.2017236113

\title{
Abstract
}

The purpose of this study was to examine whether or not "Scaffolded Think-Group-Share" learning can have a positive effect on student satisfaction and learning achievement in English classes of an Indonesian elementary school. To achieve this purpose, this study compared the findings from the two dependent variables (i.e., student satisfaction and English learning achievement) in "Scaffolded Think-Group-Share" learning with those in "Group Investigation" and "Learning Together" learning, which are other types of cooperative learning methods. According to the findings, there were statistically significant differences in student satisfaction and English learning achievement between the Scaffolded Think-Group-Share group, the Group Investigation group, and the Learning Together group. This study implies that "Scaffolded Think-Group-Share" learning has the potential to enhance student satisfaction and comprehension in English as a foreign language (EFL) classes.

Keywords: Cooperative learning, Scaffolding, Satisfaction, English learning achievement.

\section{Introduction}

The British Council (2013) reported that English is spoken by 1.75 billion people worldwide; a number that is projected to reach 2 billion by 2020. English has its status as a global language and has shown its dominance in some of the most important fields such as education, business, international relations, and politics (Crystal, 2003). Previous research found that the population's English skills are directly correlated with the country's economic performance (McCormick, 2013). This implies that proficiency in English is crucial for the welfare of individuals as well as for national development. As a result, nonEnglish speaking countries invest enormous amounts of effort into prioritizing English education and emphasizing its role in globalization (Choi, 2007; Hu \& McKay, 2012; Li, 2007; Tsui, 2004).

Meanwhile, Nunan (2003) found that many non-English speaking Asian countries have lowered the age for compulsory English education. China lowered the age from 11 to 9 in September 2011, and Korea lowered the age from 13 to 9 in 1995. In 2002, Taiwan introduced English as a compulsory subject for first graders, whereas in the past, English was first taught in the fifth grade. In Japan, English was not a compulsory subject in elementary school until April 2011, when the Ministry of Education, Culture, Science, and Technology launched the course of study for elementary schools-this required English to be compulsory starting in the fifth grade (Hu \& McKay, 2012). In Indonesia, English has been introduced to fourth graders as a local content subject since 1993 (Rachmajanti,
2008). Generally, official English education begins at the primary school level in most non-English speaking Asian countries.

The Indonesian government, in particular, has taken much interest in improving teaching strategies in elementary school English classes in order to help children acquire English more effectively (Rachmajanti, 2008). According to previous studies conducted in Indonesia, many English teachers in Indonesian elementary schools employed a rather monotonous lecture method and seldom varied their teaching methods (Dardiri, 1994; Hawanti, 2011; Mardika, 2008; Rachmajanti, 2008; Sugeng, 2000; Zein, 2012). Rachmajanti (2008) revealed that most students in the Indonesian elementary schools were unsatisfied with the teacher-centered instructional method adopted by many Indonesian English teachers and preferred to work in small groups with interactive learning activities. These findings tend to be consistent with the contention of some scholars (e.g., Curtain \& Dahlberg, 2016; Scott \& Ytreberg, 1990) that young language learners (third, fourth, and fifth graders) work well in groups and learn from each other. Huda (1997) asserted that the monotonous teaching method in the Indonesian English classes was one of most critical obstacles to how well Indonesian children learn English.

Cooperative learning is regarded as one of instructional methods that can accommodate learning preferences of the Indonesian students and meet the need of the Indonesian government for improving teaching methods in elementary school English classes. Previous empirical

\footnotetext{
a Hongik University, Seoul, Korea . E-Mail: (O. Mantik) octaviamantik@gmail.com

b,* Corresponding author: Hee Jun CHOI, Associate Professor, Hongik University, 94 Wausan-ro, Mapo-gu, Seoul, 04066, South Korea, Phone: 82-2-3201888, E-mail: hjchoi@hongik.ac.kr
} 
studies revealed that cooperative learning is effective for enhancing learning achievement, developing higher-order thinking skills, encouraging pro-social behavior, improving inter-ethnic relationships, and increasing motivation to learn (e.g., Cohen, Lotan, \& Catanzarite, 1990; Cook, 1984; High, 1993; Holt, 1993; Jacobs \& Goh, 2007; Johnson, Johnson, \& Stanne, 2000; McCafferty, Jacobs, \& DaSilva Iddings, 2006; Sharan \& Rich, 1984; Sharan \& Shaulov, 1990; Slavin, 1995).

Previous research about cooperative learning in language classes showed that as a method, it supports reading, comprehension, and vocabulary development (e.g., Slavin, Lake, Chambers, Cheung, \& Davis, 2009). Cooperative learning also tends to encourage more practice in language production (Deen, 1991). In particular, Alharbi (2008) investigated English reading performance among secondary school students aged 16 to 18 years old in Saudi Arabia and found a significant difference that favored cooperative learning compared to traditional teaching methods. Liao (2006) examined the impact of cooperative learning on the English grammar achievements of college students in Taiwan and found that cooperative learning had medium to large positive effects on grammar achievement. Nevertheless, cooperative learning is still considered neither as widely applied to young children nor systematically studied in English as foreign language (EFL) classrooms (Lan, Chang, \& Sung, 2005; Lin, 2009; Ning, 2010). This implies that the effectiveness of cooperative learning in English as a foreign language needs to be more thoroughly investigated with learners of different ages, particularly students in elementary schools, by taking a closer look at the procedures of cooperative learning.

However, other research studies show that students who experienced cooperative learning do not always outperform their counterparts who received traditional instruction. Davidson (1985) conducted a thorough review of cooperative learning in mathematics education and found that one-third of the studies showed significant differences favoring cooperative learning versus traditional methods of instruction, whereas the remaining two-third of the studies did not show significant differences. A review study focusing on Asian students revealed that only half of the studies showed that cooperative learning had any positive effect on academic achievement (Thanh, Gillies, \& Renshaw, 2008). Shaaban (2006) found no statistically significant difference between cooperative learning and whole-class instruction in improving English reading comprehension and vocabulary acquisition.

These inconsistent results of previous studies on the effectiveness of cooperative learning might be the result of differences in the main components of each cooperative learning method. Slavin (1990) argued that poorly constructed cooperative learning methods that lack the appropriate components can result in a free-rider effect, which is a major pitfall of cooperative learning. Thus, teachers should resolve the issue of free-rider effect in order to make cooperative learning more effective.

Some researchers assert that scaffolding can be designed to minimize the free-rider effect, which occurs when some group members do not their best because they assume that other group members will cover the work that they have to do (Janssen, Erkens, Kanselaar, \& Jasper, 2006). According to Wood, Bruner, and Ross (1976), scaffolding refers to the "process that enables a child or novice to solve a problem, carry out a task or achieve a goal which would be beyond his unassisted efforts" (p. 90). The researchers went on to argue that this scaffolding primarily consists of receiving support from a teacher regarding the elements of the task that are initially beyond the child's ability, so that he or she can focus on the elements that are within his or her capacity. Support for scaffolding is needed more as the task becomes more complicated and the student's ability decreases (Donovan \& Smolkin, 2002). In particular, most Indonesian elementary school students have not experienced cooperative learning and begin to learn English as a foreign language in the fourth grade. This implies that the cooperative learning that the Indonesian young children will receive needs to be integrated with well-structured scaffolding.

The concept of scaffolding is rooted in Vygotsky's social constructivist view of learning. Vygostky (1978) defined zone of proximal development as "the distance between the actual development level as determined by independent problem solving and the level of potential development as determined through problem solving under adult guidance or in collaboration with more capable peers" (p. 86). The definition of zone of proximal development implies that teaching is a process of coconstruction of knowledge between the tutor and the learner and further transformation of that knowledge into individual knowledge of the learner (Verenikina, 2008). Vygostky (1978) argued that peer interaction and scaffolding are essential in facilitating individual cognitive growth and knowledge development. This means that cooperative learning that contains well-structured scaffolding can be an effective instructional method to help children construct knowledge and become self-regulated learners.

We developed a cooperative learning method that is termed "Scaffolded Think-Group-Share" learning and is implemented to resolve the problems of passive participation and task difficulty in cooperative learning in the English classes in an Indonesian elementary school based on the findings of previous studies on cooperative learning and scaffolding (e.g., Belland, Glazewski, \& Richardson, 2008; McTighe \& Lyman, 1988; Saye \& Brush, 2002). Basically, it was developed based on the existing cooperative learning method called "Think-Pair-Share" that was developed by Frank Lyman in 1981, which includes three components: students think individually, talk with each other in pairs, and share their ideas with the larger group (McTighe \& Lyman, 1988). Additionally, "Scaffolded Think-Group-Share" learning contains "hard scaffolding," which refers to static supports that are devised in advance based on typical student difficulties with a task (Saye \& Brush, 2002) in the form of paper-based worksheet as a key component.

"Scaffolded Think-Group-Share" learning emphasizes individual activity prior to group activity by requiring students to work on a scaffolding worksheet individually to help them actively participate and cognitively engage in 
group activity. "Scaffolded Think-Group-Share" learning might be able to help students enhance their learning achievement and satisfaction toward cooperative learning activity by minimizing the "free-riding" effect and promoting individual accountability. Accordingly, this study aimed to investigate the effect of "Scaffolded Think-GroupShare" learning on student satisfaction and learning achievement in English classes of an Indonesian elementary school.

More specifically, this study was intended to compare the findings from the two dependent variables (i.e., satisfaction and English learning achievement) in "Scaffolded Think-Group-Share" learning with those in "Group Investigation" and "Learning Together" learning, which are other types of cooperative learning methods in order to reveal which cooperative learning method is most effective in children's English classes. "Group Investigation" is a cooperative learning method in which the group task is divided among the group members; thus, each member does a unique part of the group task individually before synthesizing their answers as a group. "Learning Together" is another cooperative learning method in which students do group work without any preceding individual activity.

For the purposes of this study, the following research questions were addressed:

1.Does learner satisfaction in "Scaffolded Think-GroupShare" learning differ from those in "Group Investigation" and "Learning Together" learning?

2.Do learners' English learning achievements in "Scaffolded Think-Group-Share" learning differ from those in "Group Investigation" and "Learning Together" learning?.

Table 1. Three Between-Group Quasi-Experimental Design

\begin{tabular}{lccc}
\hline $\begin{array}{l}\text { Cooperative } \\
\text { learning }\end{array}$ & $\begin{array}{c}\text { Orientation } \\
\text { session }\end{array}$ & $\begin{array}{c}\text { Right after the first, } \\
\text { second, \& third } \\
\text { cooperative learning }\end{array}$ & $\begin{array}{c}\text { Right after the third } \\
\text { cooperative learning }\end{array}$ \\
\hline$X_{S T G S}$ & $\mathrm{O}($ Pre $)$ & $O\left(\right.$ Post $_{1}$, Post $_{2}$, Post $\left._{3}\right)$ & $\mathrm{O}(\mathrm{S})$ \\
$X_{\mathrm{GI}}$ & $\mathrm{O}(\mathrm{Pre})$ & $\mathrm{O}\left(\mathrm{Post}_{1}, \mathrm{Post}_{2}, \mathrm{Post}_{3}\right)$ & $\mathrm{O}(\mathrm{S})$ \\
$\mathrm{X}_{\mathrm{LT}}$ & $\mathrm{O}(\mathrm{Pre})$ & $\mathrm{O}\left(\mathrm{Post}_{1}, \mathrm{Post}_{2}, \mathrm{Post}_{3}\right)$ & $\mathrm{O}(\mathrm{S})$ \\
\hline
\end{tabular}

Note. $\mathrm{X}_{\mathrm{STGS}}=$ "Scaffolded Think-Group-Share", $\mathrm{X}_{\mathrm{GI}}=$ "Group Investigation", $\mathrm{X}_{\mathrm{LT}}=$ "Learning Together", O= Test or Survey, (Pre)= Pretest of the first, second, and third lessons (Post 1$)=$ Comprehension test of the first lesson, $\left(\right.$ Post $\left._{2}\right)=$ Comprehension test of the second lesson, $\left(\right.$ Post $\left._{3}\right)=$ Comprehension test of the third lesson, $(\mathrm{S})=$ Satisfaction.

\section{Participants}

This research was conducted in an elementary school near Jakarta, Indonesia. Participants were 111 fifth grade students who belonged to one of the three classes. Of the 111 participants, 55 students (49.5\%) were male, and 56 students (50.5\%) were female. Each class was randomly assigned into one of the three groups (experimental group, comparison group, or control group). The numbers of the students in the experimental, comparison, and control groups were 38, 36, and 37, respectively. The three groups were taught by one English teacher who willingly agreed to participate in this study. He holds qualification as an English teacher and has taught English in the elementary school since 2001. The English teacher delivered a lecture to the students in the three groups in the week before the treatments were given and administered the treatments

\section{Methodology}

\section{Research Design and Data Collection Procedure}

This study used a three between-group, quasiexperimental design using a pretest and posttest. The details of the research design are as follows: Three fifth grade classes from an elementary school participated in this study. The three intact groups (already-formed classes) were randomly assigned to one of experimental, comparison, and control groups in the weeks that the treatments were given. Students in the experimental group were exposed to "Scaffolded Think-Group-Share" learning, students in the comparison group were exposed to "Group Investigation" learning, and students in the control group were exposed to "Learning Together" learning.

At the orientation session, all students in the three groups completed a pretest that covers all three lessons that were supposed to be taught during the experiment period. In addition, all the students in each group attended three lecture sessions from the same instructor on the first, third, and fifth week of the experiment period. The three posttests measured students' English learning achievements were administered as soon as the treatments were completed, in the second, fourth, and sixth week of the experiment period, in order to get information on the immediate learning outcomes related to the cooperative learning in which students participated. On the sixth week, students were also asked to express their satisfaction toward the cooperative learning methods that they experienced by filling-out a satisfaction questionnaire. for each group according to the lesson plans developed for this study.

\section{Instrumentation}

This study employed a survey questionnaire with a fivepoint symmetrical Likert scale that consisted of six items in order to measure students' satisfaction toward cooperative learning activities that they experienced in their groups. The questionnaire was adapted from the satisfaction subscale in the Instructional Materials Motivation Survey (IMMS) originally developed by Keller (1987). Previous research studies showed that this instrument had a Cronbach's alpha of .86 (Choi \& Johnson, 2005) and .89 (Choi \& Johnson, 2007).

Additionally, this study employed one pretest and three posttests that focused on the learning objectives of the English lessons for which the treatments were provided. 
The pretest consisted of thirty questions to measure students' prior knowledge of the contents of three lesson units to be taught during the experiment. Each posttest consisted of ten questions to measure students' immediate learning outcomes related to the cooperative learning that they received for each lesson unit. Both the pretest and posttests were divided into two sections: multiple choice and short answer questions. The questions in each posttest were identical to those in the pretest; however, the sequence of the numbers and options in the multiple-choice questions were changed randomly. The tests were developed by an English teacher who has considerable experience in setting questions for an English test. Finally, two professors reviewed the tests to check whether the content validity can be ensured.

\section{Treatments}

The treatments were given to the students in the span of six weeks. On the first, third, and fifth week of the experiment period, the students in each group (experimental, comparison, or control group) attended lecture sessions from the same English teacher. Each lecture session covered different units of English instruction. On the second, fourth, and sixth week, the students in each group participated in a different type of cooperative learning: "Scaffolded Think-Group-Share" learning (experimental treatment), "Group Investigation" learning (comparison treatment), or "Learning Together" learning (control treatment).

In "Scaffolded Think-Group-Share" cooperative learning, students progressed through three steps. In the "Scaffolded Think" component, students were asked to work on the scaffolding worksheet individually. This scaffolding worksheet was a tool designed to help students activate prerequisite knowledge and develop certain skills needed to complete the group task. The scaffolding worksheets included cues and questions that can prompt students to think about certain concepts, which are relevant to solving the corresponding group tasks. Shortly after, students continued to the "Group" component, in which they worked together with other group members to complete the group task that is related to the lesson taught by the English teacher in the previous week. In the final component, the "Share" component, groups shared their answers with the rest of the class.

The comparison group was exposed to "Group Investigation" cooperative learning, in which students were asked to divide the group task. For this activity, each group member was given a unique task to finish individually within a certain amount of time. This is also called task specialization, a means by which, according to Slavin (1983), individual accountability can be established. Each group synthesized all group members' work to complete the group task and help each other master the materials. Lastly, groups presented their answers in front of the whole class. Meanwhile, the control group was exposed to "Learning Together" cooperative learning, which is identical to the second and third components-namely, the "Group" and "Share" components-of the "Scaffolded Think-GroupShare" cooperative learning. The control group did not initiate individual activity prior to group activity.

The three classes (experimental, comparison, and control groups) had small learning groups that consisted of three or four students who were engaged in cooperative learning. The students in each class were randomly assigned to the small learning groups. Each student in the small learning group took on one of the following roles: moderator, timekeeper, note-taker, or presenter. Each group's moderator was responsible for stimulating group members to elicit their ideas, finalizing group discussion, and making sure that each group member understood the material. The timekeeper was responsible for ensuring that the group could finish the task within the given time. The note-taker's responsibilities were to take notes about group discussions and summarize explanations from the teacher. The presenter was responsible for presenting the group's answers, and answering questions from peers in other groups and the teacher as a group's spokesperson. In the small group consisting of three students, the moderator also assumed the timekeeper's role.

\section{Data Analysis}

The quantitative data used to answer the first research question were analyzed using one-way Analysis of Variance (ANOVA), which determines whether there is a statistically significant mean difference in a dependent variable between two or more groups with one independent variable (Gall, Gall, \& Borg, 2007). Additionally, this study employed Multivariate Analysis of Covariance (MANCOVA) as a statistical technique to answer the second research question. MANCOVA was used to determine whether there were significant mean differences in two or more measured variables (i.e., comprehension of the first lesson, comprehension of the second lesson, and comprehension of the third lesson) that were correlated between groups while controlling for the confounding factor (Hair, Black, Babin, \& Anderson, 2010).

\section{Results}

Differences in Learner Satisfaction between the Three Groups

One-way ANOVA was conducted to investigate whether learner satisfaction in "Scaffolded Think-Group-Share" learning differs from those in "Group Investigation" and "Learning Together" learning. The independent variable represented the different types of cooperative learning methods with three groups (i.e., the Scaffolded ThinkGroup-Share group, the Group Investigation group, and the Learning Together group). The dependent variable was the mean score that students made on a survey questionnaire that was used to gauge satisfaction toward cooperative learning activities that they experienced in their groups. The questionnaire consisted of six items scored using a five-point Likert scale. Table 2 presents the means and standard deviations of learner satisfaction for each of the three groups. 
Table 2. Means and Standard Deviations of Learner Satisfaction by Group

\begin{tabular}{lccr}
\hline Group & $n$ & $\boldsymbol{M}$ & sd \\
\hline Scaffolded Think-Group-Share & 38 & 29.00 & 1.49 \\
Group Investigation & 36 & 23.42 & 3.51 \\
Learning Together & 37 & 22.78 & 3.41 \\
Total & 111 & 25.12 & 4.06 \\
\hline
\end{tabular}

Note. Maximum high score in learner satisfaction $=30$.

The normality of the learner satisfaction variable was tested in terms of its skewness and kurtosis before further analyses could proceed. West, Finch, and Curran (1995) argue that the criteria of normality are skewness $<2$ and kurtosis $<7$. The normality assumption of learner satisfaction was met because its skewness and kurtosis were -0.58 and 0.08 , respectively. However, the Levene's $F$ test indicated that the homogeneity of variance assumption was not satisfied at the 0.05 level. Thus, the Welch's $F$ test was employed. The results of one-way ANOVA revealed that there were statistically significant differences in learner satisfaction between the Scaffolded Think-Group-Share group, the Group Investigation group, and the Learning Together group [Welch's $\Re 2,60.05)=$ 78.03, $p<.001]$.

Post hoc comparisons were conducted using the GamesHowell post hoc procedure because the homogeneity of variance assumption was not met. The results presented in Table 3 indicate that students in the Scaffolded ThinkGroup-Share group ( $M=29.00, \mathrm{sd}=1.49$ ) had a significantly higher mean score for learner satisfaction than students in the Group Investigation group ( $M=23.42$, sd= 3.51) as well as students in the Learning Together group $(M=22.78, \mathrm{sd}=$ 3.41) at the .001 level. The effect sizes for the two significant effects were 2.07 and 2.36 , respectively.

Table 3. Post Hoc Results for Learner Satisfaction by Group

\begin{tabular}{|c|c|c|c|}
\hline \multirow{2}{*}{ Group } & \multicolumn{3}{|c|}{ Mean difference (Effect size) } \\
\hline & 1 & 2 & 3 \\
\hline Scaffolded Think-Group-Share & - & & \\
\hline Group Investigation & $\begin{array}{r}-5.58^{* * *} \\
(2.07)\end{array}$ & - & \\
\hline Learning Together & $\begin{array}{r}-6.22 * * * \\
(2.36) \\
\end{array}$ & -0.63 & - \\
\hline
\end{tabular}

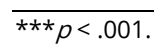

Differences in Learners' English Learning Achievements between the Three Groups

MANCOVA was employed to determine whether the type of cooperative learning (i.e., Scaffolded Think-GroupShare, Group Investigation, and Learning Together) affected students' English learning achievements while controlling for their pretest scores as the covariate. Table 4 shows the means and standard deviations of English learning achievement in the three comprehension tests for each of the three groups.

Table 4. Means and Standard Deviations in the Three Comprehension Tests by Group

\begin{tabular}{llrrr}
\hline Variables & \multicolumn{1}{c}{ Group } & $n$ & $\boldsymbol{M}$ & sd \\
\hline \multirow{4}{*}{ Comprehension 1 } & Scaffolded Think-Group-Share & 38 & 41.32 & 19.75 \\
& Group Investigation & 36 & 16.39 & 15.34 \\
& Learning Together & 37 & 15.41 & 15.02 \\
& Total & 111 & 24.59 & 20.66 \\
\hline \multirow{4}{*}{ Comprehension 2 } & Scaffolded Think-Group-Share & 38 & 65.79 & 15.53 \\
& Group Investigation & 36 & 41.39 & 15.52 \\
& Learning Together & 37 & 22.16 & 14.36 \\
& Total & 111 & 43.33 & 23.48 \\
\hline \multirow{4}{*}{ Comprehension 3 } & Scaffolded Think-Group-Share & 38 & 49.74 & 19.93 \\
& Group Investigation & 36 & 31.39 & 18.03 \\
& Learning Together & 37 & 21.35 & 19.28 \\
& Total & 111 & 34.32 & 22.37 \\
\hline
\end{tabular}

Note. Maximum high score in each comprehension test $=100$.

The test for normality indicated that the data from each comprehension test were statistically normal. The Levene's $F$ test indicated that the homogeneity of variance assumption for each dependent variable (comprehension 1,2 , and 3 ) was met at the .05 level ( $p=.36, p=.62$, and $p=$ .70 , respectively). Additionally, the results of the Box's M test showed that the assumption of covariance equality between the three groups was met at the .05 level $(p=.25)$.
Accordingly, we conducted a MANCOVA analysis. As shown in Table 5, the MANCOVA results indicate that there was a statistically significant difference in English learning achievements between students who participated in Scaffolded Think-Group-Share learning, students who participated in Group Investigation learning, and students who participated in Learning Together (Wilks' lambda= 
$0.38, p<.001$ ), with the effects of prior knowledge (Wilks' lambda $=0.78, p<.001$ ) being controlled.

More specifically, students who participated in the Scaffolded Think-Group-Share learning showed significantly higher English learning achievement than students who participated in the Group Investigation learning and students who participated in the Learning Together learning in the first and second comprehension tests at the .001 level. In the third comprehension test, students who participated in the Scaffolded Think-GroupShare learning significantly outperformed students who participated in the Group Investigation learning at the .01 level while they significantly outperformed students who participated in the Learning Together learning at the .001 level. Table 6 indicates the mean differences in the three comprehension tests between the Scaffolded ThinkGroup-Share learning, Group Investigation learning, and Learning Together learning groups and the effect sizes.

Table 5. MANCOVA Results: Multivariate Tests

\begin{tabular}{lrrr}
\hline Variables & Wilks' lambda & $F$ & $p$ \\
\hline Prior knowledge & 0.78 & 9.63 & $0.000^{\star \star \star}$ \\
Comprehension 1 & 0.38 & 21.59 & $0.000^{\star \star \star}$ \\
Comprehension 2 & & & \\
Comprehension 3 & & & \\
\hline$\star \star \star p<.001$. & &
\end{tabular}

Table 6. Contrast Analysis Results for English Learning Achievement by Group

\begin{tabular}{|c|c|c|c|c|}
\hline \multirow{2}{*}{ Variables } & \multirow{2}{*}{ Group } & \multicolumn{3}{|c|}{ Mean difference (Effect size) } \\
\hline & & 1 & 2 & 3 \\
\hline \multirow[t]{4}{*}{ Comprehension 1} & Scaffolded Think-Group-Share & - & & \\
\hline & Group Investigation & $-22.36 * \star \star$ & - & \\
\hline & & (1.41) & & \\
\hline & Learning Together & $\begin{array}{r}-21.43^{* * *} \\
(1.48)\end{array}$ & 0.94 & - \\
\hline \multirow[t]{5}{*}{ Comprehension 2} & Scaffolded Think-Group-Share & - & & \\
\hline & Group Investigation & $-24.77 * * \star$ & - & \\
\hline & & (1.57) & & \\
\hline & Learning Together & $-44.28 * * *$ & $-19.51 * \star *$ & - \\
\hline & & $(2.92)$ & (1.29) & \\
\hline \multirow[t]{5}{*}{ Comprehension 3} & Scaffolded Think-Group-Share & - & & \\
\hline & Group Investigation & $-14.70 * *$ & - & \\
\hline & & (0.97) & & \\
\hline & Learning Together & $-22.02 * * *$ & -7.31 & - \\
\hline & & (1.45) & & \\
\hline
\end{tabular}

\section{Conclusions and Discussion}

According to this study, "Scaffolded Think-Group-Share" learning is a more effective cooperative learning method for learner satisfaction than "Group Investigation" and "Learning Together" learning are in English classes for young children. This result might be supported by previous findings that indicate that college students felt more satisfied with "Think-Pair-Share" learning including a procedural scaffolding, which led to more active student participation in the group work, than other types of instructional methods (Lange, Costley, \& Han, 2016).

Because "Scaffolded Think-Group-Share" learning was developed based on "Think-Pair-Share" learning and contains hard scaffolding, it might help students activate prerequisite knowledge effectively and develop certain skills needed to complete the group task. In other words, "Scaffolded Think-Group-Share" learning contains much more elaborate and structured scaffolds than "Think-PairShare" learning, which contains a basic scaffolding, as well as "Group Investigation" and "Learning Together," which almost never contains scaffolding components. In addition, the empirical study, which was conducted by Saye and Brush (2002), revealed that hard scaffolding was helpful in decreasing learners' cognitive loads and making them engage in learning activities more actively. This implies that hard scaffolding can play a critical role in enhancing learner satisfaction in a cooperative learning environment. Consequently, individual activity on the scaffolding worksheet conducted in "Scaffolded ThinkGroup-Share" learning might have positively affected how young students had more increased satisfaction toward their cooperative learning activities in English classes by inducing more active student participation.

This study also shows that "Scaffolded Think-Group-Share" learning is more effective than "Group Investigation" and "Learning Together" learning for enhancing learner comprehension in English classes for young children. This result is congruent with the findings of previous studies. Some researchers showed that scaffolding had a positive influence on students' learning outcomes or performance in a collaborative or problem-based learning context (Huang, Wu, \& Chen, 2012; Simons \& Klein, 2007). Additionally, Pea (2004) contended that well-designed scaffoldings can help students successfully resolve and implement complex problems or tasks. 
"Scaffolded Think-Group-Share" learning included a wellstructured scaffolding component consisting of cues and questions that prompted students to think about certain concepts that were relevant for solving the corresponding group tasks. This scaffolding component of "Scaffolded Think-Group-Share" learning might have helped students cognitively engage in the group task by activating prerequisite knowledge individually prior to group activity. This might be the crucial reason why students in "Scaffolded Think-Group-Share" group outperformed their counterparts in "Group Investigation" and "Learning Together" groups in the three comprehension tests.

This study might be significant in that it was an initial effort to determine the actual impact of individual activity using hard scaffolds in cooperative learning. Additionally, there are few empirical studies on cooperative learning that have been conducted with young children in EFL classrooms (Lan, Chang, \& Sung, 2005; Lin, 2009; Ning, 2010). Consequently, the findings of this study contribute to expanding and fortifying the existing knowledge base regarding cooperative learning using well-structured scaffolding.

\section{Limitations and Suggestions for Future Research}

This study has the following limitations, despite its significance. First, the findings of this study may not be generalized to all elementary students because the sample was selected only from those students who attend an elementary school near Jakarta, Indonesia. Accordingly, future research studies should be implemented that use a more extensive and larger sample in terms of regional, ethnical, and cultural backgrounds so that the findings can be generalized to all elementary students. Second, the findings of this study were drawn from only quantitative data, which provides limited information regarding the relative advantages of "Scaffolded Think-Group-Share" learning. Future research studies need to produce findings using both quantitative and qualitative data in order to provide in-depth information on "Scaffolded Think-GroupShare" learning.

\section{Acknowledgement:}

This work was supported by the Hongik University Research Fund.

\section{References}

Alharbi, L. A. (2008). The effectiveness of using cooperative learning method on ESL reading comprehension performance, students' attitudes toward $C L$, and students' motivation toward reading of secondary stage in Saudi public girls' schools (Doctoral dissertation, West Virginia University). Retrieved from http://search.proquest.com/docview/304448780

Belland, B., Glazewski, K., \& Richardson, J. (2008). A scaffolding framework to support the construction of evidence-based arguments among middle school students. Educational Technology Research and Development, 56(4), 401-422.

British Council. (2013). The English effect. Retrieved from https://www.britishcouncil.org/sites/default/files/engli sh-effect-report-v2.pdf
Choi, H., \& Johnson, S. D. (2005). The effect of contextbased video instruction on learning and motivation in online courses. The American Journal of Distance Education, 19(4), 215-227.

Choi, H., \& Johnson, S. D. (2007). The effect of problembased video instruction on learner satisfaction, comprehension and retention in college courses. British Journal of Educational Technology, 38(5), 885895.

Choi, Y. H. (2007). The history of and the policy of the English language education in Korea. In Y. H. Choi \& B. Spolsky (Eds.), English education in Asia: History and policies (pp. 33-66). Seoul: Asia TEFL.

Cohen, E. G., Lotan, R. A., \& Catanzarite, L. (1990). Treating status problems in the cooperative classroom. In S. Sharan (Ed.), Cooperative learning: Theory and research (pp. 173-202). New York: Praeger.

Cook, S. (1984). Cooperative interaction in multiethnic contexts. In N. Miller \& M. Brewer (Eds.), Groups in contact: The psychology of desegregation (pp. 77-96). New York: Academic.

Crystal, D. (2003). English as a global language (2nd ed.). Cambridge: Cambridge University Press.

Curtain, H., \& Dahlberg, C. A. (2016) Languages and learners: Making the match. Boston: Pearson.

Dardiri, H. (1994). A study on the teaching of English at some elementary schools in Kodya Malang (Unpublished thesis). IKIP Malang, Indonesia.

Davidson, N. (1985). Small group learning and teaching in mathematics: A selective review of the research. In R. Slavin, S. Sharan, S. Kagan, R. Hertz-Lazarowitz, G. Webb, \& R. Schmuck (Eds.), Learning to cooperate, cooperating to learn. New York: Plenum.

Deen, J. Y. (1991). Comparing interaction in a cooperative learning and teacher-centered language classroom. I. T. L. Review of Applied Linguistics, 153-181.

Donovan, C. A., \& Smolkin, L. B. (2002). Children's genre knowledge: An examination of K-5 students' performance on multiple tasks providing differing levels of scaffolding. Reading Research Quarterly, 37, 428-465.

Gall, M. D., Gall, J. P., \& Borg, W. R. (2007). Educational research: An introduction (8th ed.). Berkshire: Allyn and Bacon.

Hair, J. F., Black, W. C., Babin, B. J., \& Anderson, R. E. (2010). Multivariate Data Analysis (7th ed.). Upper Saddle River, NJ: Pearson.

Hawanti, S. (2011). Teaching English in Indonesian primary schools: The missing link. Leksika, 5(1), 62-69.

High, J. (1993). Second language learning through cooperative learning. San Juan Capistrano, CA: Kagan Cooperative Learning.

Holt, D. (Ed.). (1993). Cooperative learning: A response to linguistic and cultural diversity. McHenry, IL: Centre for Applied Linguistics. 
Hu, G. W., \& McKay, S. L. (2012). English language education in East Asia: Some recent developments. Journal of Multilingual and Multicultural Development, 33(4), 345362.

Huang, H., Wu, C., \& Chen, N. (2012). The effectiveness of using procedural scaffoldings in a paper-plussmartphone collaborative learning context. Computers \& Education, 59(2), 250-259.

Huda, N. (1994). The teaching of English in primary schools: Issues and problems. TEFLIN Journal, 6(2), 82-90.

Jacobs, G. M., \& Goh, C. C. (2007). Cooperative learning in the language classroom. Singapore: SEAMEO Regional Language Centre.

Janssen, J., Erkens, G., Kanselaar, G., \& Jasper, J. (2006). Visualization of participation: does it contribute to successful computer-supported collaborative learning? Computers \& Education, 49(4), 1037-1065.

Johnson, D. W., Johnson, R. T., \& Stanne, M. E. (2000). Cooperative learning methods: $A$ meta-analysis. Minneapolis, MN: University of Minnesota Press.

Keller, J. M. (1987). Development and use of the ARCS model of instructional design. Journal of Instructional Development, 193), 2-10.

Lan, Y. J., Chang, K. E., \& Sung, Y. T. (2005). Cooperative learning in small EFL early reading groups. Journal of Pan-Pacific Association of Applied Linguistics, 9(2), 319341.

Lange, C., Costley, J., \& Han, S. L. (2016). Informal cooperative learning in small groups: The effect of scaffolding on participation. Issues in Educational Research, 26(2), 260-279.

Li, M. (2007). Foreign language education in primary schools in the People's Republic of China. Current Issues in Language Planning, 8(2), 148-160. doi: 10.2167/cilp113.0

Liao, H. C. (2006). Effects of Cooperative Learning on Motivation, Learning Strategy Utilization, and Grammar Achievement on English language Learners in Taiwan (Doctoral dissertation, University of New Orleans). Retrieved from http://scholarworks.uno. edu/cgi/viewcontent.cgi?article=1362\&context $=$ td

Lin, M. (2009). Effects of cooperative learning on the oral proficiency of Chinese students in the tertiary-level EFL classroom (Doctoral dissertation, University of Leicester). Retrieved from https:///ra.le.ac.uk/bitstream /2381/8941/1/2009linmxedd.pdf

Lyman, F. (1981). The responsive classroom discussion. In A. S. Anderson (Ed.), Mainstreaming Digest (pp. 109113). College Park, MD: University of Maryland College of Education.

Mardika, I. N. (2008). Pengembangan multimedia dalam pembelajaran kosakata Bahasa Inggris di SD [The development of multimedia for English vocabulary learning in elementary school] (Unpublished thesis). Yogyakarta State University, Indonesia.
McCafferty, S. G., Jacobs, G. M., \& DaSilva Iddings, A. C. (Eds.). (2006). Cooperative learning and second language teaching. Cambridge: Cambridge University Press.

McCormick, C. (2013, November 15). Countries with better English have better economies. Harvard Business Review. Retrieved from https://hbr.org/2013/11/ countries-with-better-english-have-better-economies

McTighe, J. \& Lyman, F. T. (1988). Cueing thinking in the classroom: The promise of theory-embedded tools. Educational Leadership, 45(7), 18-24.

Ning, H. (2010). An investigation of the use of cooperative learning in teaching English as a foreign language with tertiary education learners in China (Doctoral dissertation, University of Canterbury). Retrieved from https://ir.canterbury.ac.nz/bitstream/handle/10092/51 88/thesis_fulltext.pdf?sequence $=1$ \&isAllowed $=y$

Nunan, D. (2003). The impact of English as a global language on educational policies and practices in the Asia-Pacific region. TESOL Quarterly, 374), 589-613.

Pea, R. D. (2004). The social and technological dimensions of scaffolding and related theoretical concepts for learning, education, and human activity. Journal of the Learning Sciences, 13(3), 423-451.

Rachmajanti, S. (2008). Impact of English instruction at the elementary schools on the students' achievement of English at the lower secondary school. TEFLIN Journal, 19(2), 160-185.

Saye, J. W., \& Brush, T. (2002). Scaffolding critical reasoning about history and social issues in multimediasupported learning environments. Educational Technology Research and Development, 503), 77-96.

Scott, W. A., \& Ytreberg, L. H. (1990). Teaching English to children. New York: Longman.

Shaaban, K. (2006). An initial study of the effects of cooperative learning on reading comprehension, vocabulary acquisition, and motivation to read. Reading Psychology, 275), 377-403. doi: $10.1080 / 02702710600846613$

Sharan, S., \& Rich, Y. (1984). Field experiments on ethnic integration in Israeli schools. In Y. Amir \& S. Sharan (Eds.), School desegregation (pp. 189-217). Hillsdale, NJ: Lawrence Erlbaum Associates, Inc.

Sharan, S., \& Shaulov, A. (1990). Cooperative learning, motivation to learn, and academic achievement. In S. Sharan (Ed.), Cooperative learning: Theory and research (pp. 173-202). New York: Praeger.

Slavin, R. E. (1983). Cooperative learning. New York: Longman.

Slavin, R. E. (1990). Cooperative learning: Theory, research and practice. Englewood Cliffs, NJ: Prentice Hall.

Slavin, R. E. (1995). Cooperative learning: Theory, research, and practice (2nd ed.), Boston: Allyn and Bacon.

Slavin, R. E., Lake, C., Chambers, B., Cheung, A., \& Davis, S. (2009). Effective reading programs for the elementary 
grades: A best-evidence synthesis. Review of Educational Research, 79, 1391-1466.

Sugeng, B. (2000). Pembelajaran Bahasa Inggris untuk anak: Sifat-sifat pembelajaran yang baik [English learning for children: Good learning characteristics] (Unpublished paper). Yogyakarta State University, Indonesia.

Thanh, P. T. H., Gillies, R., \& Renshaw, P. (2008). Cooperative learning and academic achievement of Asian students: A true story. International Education Studies, 1, 83-88.

Tsui, A. B. M. (2004). Language policies in Asian countries: Issues and tensions. The Journal of Asia TEFL, 1, 1-25.

Verenikina, I. (2008). Scaffolding and learning: Its role in nurturing new learners. In P. Kell, W. Vialle, D. Konza \& G. Vogl (Eds.), Learning and the learner: Exploring learning for new times (pp. 161-180). Wollongong, Australia: University of Wollongong.

Vygotsky, L. (1978). Mind in society: The development of higher psychological processes. Cambridge, MA: Harvard University Press.

West, S.G., Finch, J.F. \& Curran, P.J. (1995). Structural equation models with nonnormal variables. Problems and remedies. In R.H. Hoyle (Ed.), Structural equation modeling: Concepts, issues and applications (pp. 5675). Newbury Park, CA: Sage.

Wood, D., Bruner, J. S., \& Ross, G. (1976). The role of tutoring in problem-solving. Journal of Child Psychology and Psychiatry and Allied Disciplines, 17, 89-100.

Zein, M. S. (2012). Language teacher education for primary school English teachers in Indonesia: Policy recommendations (Doctoral dissertation, Australian National University). Retrieved from https://open research-repository.anu.edu.au/bitstream/1885/9981/ 1/Zein_M.S._2012.pdf 
This page is intentionally left blank

www.iejee.com 